\title{
Peningkatan Peran Pendakwah Perempuan di Masyarakat di Desa Sananwetan Kecamatan Sananwetan Kota Blitar Analisis Teori Kelompok Bungkam (Muted Group Theory) dan Teori Feminisme
}

\author{
Nurliya Ni’matul Rohmah \\ Program Studi Komunikasi Penyiaran Islam, Fakultas Agama Islam \\ Universitas Muhammadiyah Mataram,83115, Indonesia \\ nr.nurliya@gmail.com
}

Riwayat Artikel:

Diterima Desember 2017

Direvisi Januari 2018

Disetujui Februari 2018

\begin{abstract}
Abstrak: Fokus penelitian ini adalah bagaimana nilai seorang pendakwah perempuan dalam dakwah Islam serta peran pendakwah perempuan dalam peningkatan dakwah Islam di desa Sananwetan kecamatan Sananwetan kota Blitar? Untuk mengidentifikasi permasalahan tersebut secara mendalam dan menyeluruh, peneliti menggunakan paradigma penelitian fenomenologi. Adapun pendekatan yang digunakan adalah pendekatan kualitatif, karena penelitian ini berusaha menangkap dan memahami realitas sosial ataupun fenomena yang ada. Selain itu tujuan penulis dalam penelitian ini adalah ingin mengetahui nilai seorang pendakwah perempuan serta perannya dalam peningkatan dakwah Islam di desa Sananwetan yang dianalisis menurut teori kelompok bungkam dan feminisme. Data dalam penelitian ini diperoleh melalui 3 cara, yakni dengan metode wawancara, observasi dan studi dokumentasi serta didukung dengan menggunakan teknik sosiometri. Syari'at Islam memberikan kewajiban yang sama kepada laki-laki dan perempuan untuk menjalankan dakwah. Meskipun dalam stratafikasi tanggung jawab berbeda. Perjuangan pendakwah perempuan di desa Sananwetan untuk meningkatkan perannya dalam dakwah agar seimbang dengan para pendakwah laki-laki di masyarakat desa Sananwetan, pada awalnya kurang dapat diterima oleh masyarakat desa Sananwetan itu sendiri. Mereka terbungkam secara psikologis oleh suami dalam batasan waktu dan wilayah dakwah, serta budaya masyarakat yang kurang berkenan dengan adanya seorang pendakwah perempuan. Pada akhirnya, dalam penelitian ini ditemukan bahwa setelah adanya gerakan feminisme pendakwah perempuan yang dikembangkan oleh Ibu Salamah dalam kegiatan khataman al-Qur'an dan peduli kasihnya serta Ibu Utami dalam kegiatan arisan qurbannya, menjadikan nilai mereka sebagai seorang pendakwah perempuan terangkat di mata masyarakat. Sehingga peranan mereka dalam dakwah sudah dianggap setara sebagai pendamping ataupun mitra bagi pendakwah laki-laki dan kaum lakilaki lainnya tidak hanya dalam dakwah, namun juga pada ranah yang lain. Penelitian ini belumlah sempurna, untuk itu peneliti membutuhkan saran-saran mendukung sebagai rekomendasi penelitian ke depan.
\end{abstract}

\begin{abstract}
Focus of this research is how the value of a women preachers in Islamic da'wah and the role of women preachers in increasing Islamic da'wah in Sananwetan village, Sananwetan subdistrict, Blitar city? To identify the problems deeply and thoroughly, the researcher uses a phenomenological paradigm research. Approached used is a qualitative approach, because this research seeks to capture and understand the social reality or existing phenomena. In addition, the author's purpose in this research is to know the value of a women preacher and her role in increasing Islamic da'wah in the village of Sananwetan analyzed according to
\end{abstract}


Kata Kunci:

Pendakwah Perempuan,

Teori Kelompok Bungkam,

Feminisme

Keywords:

Female Preachers,

Muted Group Theory,

Feminism the theory of silence group and feminism. The data in this research is obtained through 3 ways ie by interview method, observation and documentation study and supported by using sociometric technique. Islamic Shari'ah gives the same obligation to men and women to carry out da'wah. Even though the stratafication of responsibilities is different. The struggle of women preachers in Sananwetan village to increase their role in da'wah to be balanced with male preachers in Sananwetan village community was initially less acceptable to the people of Sananwetan village itself. They are psychologically silenced by husbands within the timeframe and dakwah area, as well as the culture of the people who are less pleased with the presence of women preachers. In the end, in this research found that after the movement of feminism of women preachers developed by Mrs. Salamah in activity of khataman al-Qur'an with her caring and love and Mrs. Utami in arisan qurban activity, made their value as a woman preacher lifted in society eye. So, their role in da'wah is considered equal as a companion or partner for the preacher of men and not only in da'wah, but also in other realms. This research is not perfect yet, for that researchers need supportive suggestions as research recommendations in the future.

\section{Pendahuluan}

Tembang gending Jawa "Lir Ilir", dalam liriknya terdapat kalimat "mumpung padhang rembulan'e", yang menafsirkan makna "Selagi kita masih memiliki seorang Guru atau juga Pendakwah dalam kehidupan ini" . Tatkala manusia dilanda kegersangan spiritual, rapuhnya akhlak, maraknya korupsi, kolusi dan manipulasi, ketimpangan sosial, kerusuhan, kecurangan dan sederet tindakan-tindakan lainnya. Jelas bahwa dakwah merupakan seruan atau ajakan kepada keinsafan, atau usaha mengubah situasi yang buruk kepada situasi yang lebih baik dan sempurna.

Kondisi masyarakat di Desa Sananwetan Kecamatan Sananwetan Kota Blitar merupakan kondisi yang heterogen, disana terdapat pedagang, guru, karyawan, pejabat, petani, pengangguran, dan lain-lain, sehingga kondisi yang heterogen seperti itu merupakan lahan yang potensial untuk berdakwah. Selain itu karakteristik masyarakatnya yang memiliki sistem nilai budaya (aturan moral) yang mengikat dan dipedomani warganya dalam melakukan interaksi sosial. Aturan itu umumnya tidak tertulis, aturan seperti perempuan itu harus tunduk, patuh dan tergantung pada suaminya.

Di Desa Sananwetan Kecamatan Sananwetan Kota Blitar sendiri, terdapat sekitar 5 (lima) Kyai dan 10 (sepuluh) Ustadz yang tampak berkecimpung dalam dakwah di lingkungan Desa. Sebenarnya, terdapat 2 (dua) ustadzah yang juga terlibat dalam dakwah Islam, namun jam terbang dakwah mereka sedikit terbatas, dikarenakan mereka adalah seorang ibu rumah tangga, yang notabene juga berkewajiban mengurusi rumah tangganya serta terbatasnya izin dari suami dan budaya lingkungan mereka masing-masing untuk berdakwah sampai batas-batas tertentu.

Peran seorang laki-laki dalam dakwah di Desa Sananwetan Kecamatan Sananwetan Kota Blitar cenderung dominan. Mereka memimpin beberapa jamaah laki-laki maupun perempuan serta mengisi berbagai pengajian, baik di desa maupun di luar desa Sananwetan. Selain itu, keterlibatan mereka menjadi takmir di berbagai masjid di desa Sananwetan serta kepercayaan masyarakat untuk menjadikan mereka sebagai pentolan desa.

Berbeda dengan seorang peran perempuan dalam dakwah di desa Sananwetan kecamatan Sananwetan kota Blitar, mereka cendurung terbatasi, baik dari segi waktu maupun wilayah. Mereka hanya diberikan kesempatan untuk memimpin sebuah jamaah perempuan yasin dan tahlil, jikalau "ustadz" mereka berhalangan hadir, selain itu ide-ide mereka yang menyangkut dakwah Islam seperti arisan qurban dan peduli kasih dalam hal pemberdayaan masyarakat masih disepelekan, dan pada akhirnya diakui sebagai ide dari para pendakwah laki-laki.

Dalam masyarakat lingkungan sekitar Desa Sananwetan Kecamatan Sananwetan Kota Blitar, hanya sedikit perempuannya yang bebas bersuara apalagi memiliki kedudukan ataupun peran 
yang penting dalam masyarakat. Baik itu di bagian pemerintahan (RT ataupun RW) ataupun berdakwah di pengajian-pengajian yang berupa yasinan ataupun tahlilan. Semuanya di dominasi oleh kaum lelaki, padahal taklif hukum (beban hukum) yang sama bagi laki-laki dan perempuan karena ayat-ayat maupun hadits-hadits yang menunjuk kepada hukum tersebut bersifat umum bagi manusia.

Dari penelitian selanjutnya ditemukan, bahwa emansipasi para pendakwah perempuan di desa Sananwetan menciptakan sebuah revolusioner dakwah kelompok yang kiranya tidak melanggar norma yang telah ditetapkan oleh suami ataupun budaya lingkungan mereka.

Pembungkaman yang secara psikologis dilakukan oleh para suami dan budaya lingkungan mereka yang berupa batasan waktu dan wilayah, disiasati dengan membentuk jamaah pengajian khataman al-Qur'an rutinan hari Jum'at di siang hari, mulai jam 2 hingga jam 4 sore WIB, yang diikuti oleh ibu-ibu dari wilayah dalam maupun luar desa Sananwetan, yang kemudian mereka akan bergantian tempat pelaksanaan khataman al-Qur'an tersebut dari ibu satu ke ibu yang lain. Hal ini dilakukan agar pembatasan wilayah yang dilakukan dapat diatasi dengan baik.

Selain itu, kegiatan arisan qurban yang merupakan ide dari ibu Utami, terpaksa terbungkam karena kedudukan dia yang hanya sebagai ibu rumah tangga dan tidak mendapat sambutan yang antusias dari warga, namun setelah ide tersebut diambil oleh bapak RT setempat, banyak warga yang berbondong-bondong berpartisipasi dalam kegiatan tersebut. Upaya yang dilakukan oleh ibu Utami selanjutnya adalah memastikan dan menyakinkan warga masyarakat bahwa uang arisan tersebut akan lebih terjamin dan aman apabila dipegang oleh para kaum perempuan sebagai panitianya.

Dari peran-peran yang telah penulis jabarkan di atas, tampaklah bahwa selama ini perempuan berjuang untuk kembali menempati posisi yang sudah seharusnya sudah ditempatinya sejak zaman dulu, perjuangan perempuan melawan keterikatan pada hubungan kekuasaan yang menempatkannya pada kedudukan lebih rendah dibandingkan laki-laki memang merupakan perjuangan sepanjang hidupnya.

Perempuan juga mengalami pembungkaman dan pembisuan yang berdampak pada diskriminasi dalam bentuk seperti perempuan tidak boleh berpendapat, tidak berani mengungkapkan keinginannya atau persoalan yang dialami. Selain itu, perempuan juga sering diremehkan ketika berbicara sesuatu yang dianggap tidak penting oleh laki-laki, tidak punya kendali dalam pengambilan keputusan, tidak bisa membela diri meskipun benar dan selalu disalahkan. Seperti kondisi perempuan yang ada di Desa Sananwetan Kecamatan Sananwetan Kota Blitar.

Feminisme yang dilakukan merupakan sebuah gerakan para pendakwah perempuan untuk menyuarakan dengan lantang tentang perbaikan kedudukan dan menolak perbedaan derajat antara laki-laki dan perempuan. Mereka berusaha menjadi sama dalam hal kewajiban mereka berdakwah, tidak terbatas pada segi waktu ataupun wilayah. Namun tetap saja mereka tetap berpijak pada norma-norma yang ada serta kepatuhan aturan seorang perempuan yang notabene adalah seorang istri kepada suami dan rumah tangganya.

Identifikasi dan Batasan Masalah dari Penelitian ini adalah berdasar pada teori kelompok bungkam dan teori feminisme. yaitu fenomena pembungkaman yang terjadi di desa Sananwetan Kota Blitar perihal pendakwah perempuan, kemudian peneliti komparasikan menggunakan teori feminisme liberal sebagai upaya emansipasi mereka, maka agar lebih terfokus pada kajian penelitian yang akan dirumuskan, (1) Nilai pendakwah perempuan di desa Sananwetan kecamatan Sananwetan Kota Blitar (2) Upaya perempuan dalam peningkatan peran dalam dakwah di desa Sananwetan kecamatan Sananwetan Kota Blitar.

Sehingga Rumusan Masalah dalam Penelitian ini adalah "Bagaimanakah nilai seorang pendakwah perempuan serta upayanya dalam peningkatan peran dakwah Islam di Desa Sananwetan Kecamatan Sananwetan Kota Blitar menurut analisis teori kelompok bungkam dan feminisme?" 
Adapun Tujuan Penelitian ini adalah (1) Mengetahui sejauh mana nilai seorang pendakwah perempuan di masyarakat terutama dalam dakwah Islam. (2) Mengetahui upaya para pendakwah perempuan untuk peningkatan peran dalam dakwah di desa Sananwetan kecamatan Sananwetan Kota Blitar (3) Memberikan kontribusi pemikiran dalam kajian teori kelompok bungkam yang terfokus pada peran perempuan di masa kini dan mendatang.

Dalam pelaksanaan penelitian ini, peneliti berharap dapat memberikan manfaat secara teoritis yaitu dengan mengkaji nilai pendakwah perempuan dan upaya peningkatan kegiatan dakwah Islam di Desa Sananwetan Kecamatan Sananwetan Kota Blitar yang di analisis melalui teori kelompok bungkam dan feminisme di atas, diharapkan hasil penelitian ini dapat membantu pembaca untuk memahami teori kelompok bungkam dan feminism yang merupakan teori komunikasi kritis dan termasuk dalam konteks kultural yang membahas mengenai gender dan komunikasi. Dan secara praktis yaitu Teori ini memusatkan perhatiannya pada kelompok tertentu dalam masyarakat yang mengungkap struktur-struktur penting yang menyebabkan penindasan dan memberikan arah bagi perubahan yang positif yaitu, sebuah peran penting bagi seorang perempuan untuk berkecimpung dalam masyarakatnya, terutama dalam dakwah Islam. Selain itu, manfaat hasil penelitian ini dapat digunakan sebagai pembanding bagi peneliti lain dalam pengkajian yang serupa pada umumnya.

\section{Kajian Pustaka dan Teoritik}

\section{A. Kajian Pustaka}

\section{1) Tinjauan Tentang Peran Pendakwah}

Dakwah, pada hakikatnya adalah upaya sadar untuk mempengaruhi dan mengajak orang lain, atau kelompok tertentu, agar mau mengikuti jalan kebenaran. ${ }^{1}$ Dakwah menurut Ahmad Ghalwusy adalah menyampaikan pesan Islam kepada manusia di setiap waktu dan tempat dengan metode-metode dan media-media yang sesuai dengan situasi dan kondisi para penerima pesan dakwah (khalayak dakwah). ${ }^{2}$ Fungsi dakwah dan peranannya, tidak lain adalah memberikan jalan keluar yang benar dan tepat kepada umat manusia dari berbagai macam situasi yang serba kelam (darkness) menuju situasi yang terang (brightness). ${ }^{3}$ Pendakwah adalah orang yang melakukan dakwah. Ia disebut juga da'i atau da'iyah. Dalam ilmu komunikasi pendakwah adalah komunikator yaitu orang yang menyampaikan pesan komunikasi (message) kepada orang lain.

\section{2) Tinjauan Tentang Nilai Pendakwah Perempuan}

Penulis menggunakan kata perempuan dalam penelitian ini, karena kata perempuan berhubungan dengan kata ampu 'sokong', 'memerintah', 'penyangga', 'penjaga keselamatan', bahkan 'wali' ; kata mengampu artinya 'menahan agar tak jatuh' atau 'menyokong agar tidak runtuh'; kata mengampukan berarti 'memerintah (negeri)' ; ada lagi pengampu 'penahan, penyangga, penyelamat', sehingga ada kata pengampu susu ' kutang' alias 'BH' .

Kata perempuan juga berakar erat dari kata empuan; kata ini mengalami pemendekan menjadi puan yang artinya ' sapaan hormat pada perempuan', sebagai pasangan kata tuan ' sapaan hormat pada lelaki'. ${ }^{4}$ Penggunaan kata "perempuan" berbeda dengan "perempuan", istilah "perempuan" dapat merujuk kepada orang yang telah dewasa maupun yang masih anak-anak . Sedangkan kata "perempuan" adalah kata yang umum digunakan untuk menggambarkan perempuan dewasa.

\footnotetext{
${ }^{1}$ Nazaruddin "Publistik dan Dakwah" (Jakarta: Erlangga, 1974), 87

${ }^{2}$ Ahmad Subandi dan Syukriadi Sambas, Dasar-Dasar Bimbingan (Irsyad) dalam Dakwah Islam, (Bandung: KP Hadid, 1999), 18

${ }^{3}$ Said Bin Ali Al Qahthani. Dakwah Islam Da'wah Bijak; (Jakarta: Gema Insani Press, 1994), 101.

${ }^{4}$ Ilyas, "Betina", dalam http ://www.angelfire.com/journal/fsulimelight/betina.html, (25 Desember 2011), 1.
} 
Dari pengertian di atas, penulis berasumsi bahwa penggunaan kata "perempuan" merupakan kata yang tepat dalam penelitian ini, karena kata "perempuan" mencakup seluruh usia, baik ibu, perempuan maupun anak gadis. Menurut al-Qur'an, perempuan dan laki-laki mempunyai spiritual human-nature yang sama. Al-Qur'an menyebutkan bahwa kedua jenis kelamin, laki-laki dan perempuan, masing-masing berdiri sendiri dan independen. Al-Qur'an sama sekali tidak pernah menyebutkan bahwa Hawa diciptakan dari tulang rusuk Adam, bahkan isu tentang jenis kelamin mana yang lebih dahulu diciptakan, al-Quran tidak memberikan spesifikasi yang jelas. ${ }^{5}$

\section{B. Kajian Teoritik}

\section{1) Tinjauan Pustaka tentang Teori Kelompok Bungkam}

Muted Group Theory (Teori Kelompok Bungkam) diteliti oleh Cheris Kramarae yang menjelaskan tentang bagaimana seorang perempuan yang merupakan kaum subordinat berusaha untuk berkomunikasi layaknya seorang laki-laki dalam mendeskripsikan pengalaman yang mereka alami. Untuk mengekspresikan pengalamannya melalui bahasa, dibutuhkan suatu proses, yang mana proses tersebut membuat para perempuan cenderung lambat dan kesulitan dalam mengartikulasikan pemikirannya ke dalam suatu bahasa yang fasih. ${ }^{6}$

Teori ini berfokus pada perempuan sebagai muted group. Namun, sebenarnya teori ini tidak hanya dapat berlaku pada perempuan, teori ini berlaku bagi semua kelompok yang nondominan. Perspektif ini membawa kita melihat pada keberadaan kelompok dominan, yang mana merupakan kelompok yang memegang kekuasaan dalam suatu budaya. Kelompok lain yang non-dominan otomatis menjadi subordinat, sehingga mereka tidak memiliki akses dalam kekuasaan kelompok dominan. ${ }^{7}$

\section{2) Tinjauan Pustaka tentang Teori Feminisme Liberal}

Teori-teori feminis muncul secara khusus menyoroti kedudukan perempuan. Teori-teori ini berupaya untuk menggugat kemapanan patriarkhi dan berbagai bentuk stereotip gender lainnya yang berkembang luas di dalam masyarakat. ${ }^{8}$

Feminisme liberal merupakan aliran yang berusaha memasukkan ide bahwa perempuan merupakan makhluk yang sama dengan pria, dan mempunyai hak yang sama pula dengan pria. Feminisme liberal memberikan landasan teoritis akan kesamaan dalam hal potensi rasionalitasnya. Namun berhubung perempuan ditempatkan pada posisi bergantung pada lakilaki (suami) dan kiprahnya ditentukan dalam sektor domestik, maka yang lebih dominan tumbuh pada perempuan adalah aspek emosional daripada rasional. Bila perempuan tidak bergantung pada suami dan tidak berkiprah di sektor domestik, maka ia akan menjadi makhluk rasional seperti laki-laki. ${ }^{9}$. Meskipun demikian, feminisme liberal tidak menuntut persamaan menyeluruh antara laki-laki dan perempuan. Dalam beberapa hal terutama yang berhubungan dengan fungsi reproduksi, aliran ini masih tetap memandang perlu adanya pembedaan (distinction) antara laki-laki dan perempuan. Kelompok ini termasuk paling moderat di antara kelompok feminis. ${ }^{10}$

\footnotetext{
${ }^{5}$ Lily Zakiyah Munir (Ed.), Memposisikan Kodrat, (Bandung: Mizan, 1999), 11

${ }^{6}$ Griffin, EM, A First Look At Communication Theory. Fifth Edition. (New York, McGraw-Hill Companies, Inc. America, 2003), 487

7 Richard West dan Lynn.H. Turner, Introducing Communication Theory: Analysis and Aplication, (Pengantar Teori Komunikasi Analisis dan Aplikasi), edisi 3, Penerjemah Maria Natalia Damayanti Maer (Jakarta: Salemba Humanika, 2008$), 183$.

${ }^{8}$ Umar, N, Argumen Kesetaraan Jender: Perspektif Al Qur'an, (Jakarta: Paramadina, 1999), 64

${ }^{9}$ Megawangi, R, Membiarkan Berbeda? : Sudut Pandang Baru tentang Relasi Gender, (Bandung, Mizan, 1999), 118-119

${ }^{10}$ Umar, N, Argumen Kesetaraan Jender: Perspektif Al Qur'an, (Jakarta: Paramadina, 1999), 64
} 


\section{Metode Penelitian}

\section{A. Pendekatan dan Jenis Penelitian}

Dilihat dari pendekatannya, penelitian ini menggunakan penelitian kualitatif. Penelitian kualitatif adalah penelitian yang berakar pada latar alamiah sebagai keutuhan, mengandalkan manusia sebagai instrument pengumpul data, mengandalkan analisis data secara induktif, mengarah pada penemuan teori, bersifat deskriptif, lebih mementingkan proses daripada hasil, membatasi studi dengan fokus, memiliki kriteria untuk memeriksa keabsahan data, rancangannya bersifat sementara dan kesimpulan penelitian disepakati oleh peneliti dan subyek yang diteliti. ${ }^{11}$

Dalam penelitian ini, yang merupakan penelitian kualitatif, pengumpulan data tidak dipandu oleh teori bungkam ataupun feminisme, tetapi dipandu oleh fakta-fakta atau fenomena yang ditemukan pada saat penelitian pada pendakwah perempuan di desa Sananwetan. Oleh karena itu, analisis data yang dilakukan bersifat induktif berdasarkan fakta-fakta yang ditemukan dan kemudian dapat dikontruksikan menjadi hipotesis atau teori. ${ }^{12}$

Penulis menggunakan pendekatan kualitatif pada tesis ini, karena penulis mempunyai pertimbangan tersendiri, yaitu bahwa dari rumusan masalah pada tesis ini menuntut digunakannya model kualitatif. Hal tersebut dikarenakan dalam rumusan masalah yang ada yakni penulis ingin mengetahui nilai seorang pendakwah perempuan serta upayanya dalam peningkatan dakwah Islam di Desa Sananwetan Kecamatan Sananwetan Kota Blitar menurut analisis teori kelompok bungkam dan feminisme dan tidak untuk mengukur variabel.

Pendekatan atau paradigma sebagai sudut pandang atau cara melihat suatu permasalahan yang menjadi perhatian peneliti dalam penelitian ini adalah paradigma fenomenologi. ${ }^{13}$ Fenomenologi merupakan cara yang digunakan peneliti untuk memahami kondisi lapangan melalui pengalaman langsung. Mengetahui permasalahan itu dengan sadar, menganalisis dan menguji persepsi tentang permasalahan tersebut. ${ }^{14}$

\section{B. Subjek dan Objek Penelitian}

Subjek penelitian ini dilakukan terhadap peran perempuan yang terbungkam secara psikologis oleh budaya lingkungan dan suaminya dalam berdakwah di Desa Sananwetan Kecamatan Sananwetan Kota Blitar. Adapun objek penelitiannya adalah salah satu ibu rumah tangga yang perannya terbungkam dalam berdakwah (contoh fenomena pada Ibu Salamah) yang kegiatannya berupa yasinan pada malam senin, yang mana beliau tidak bisa secara bebas memimpin kegiatan tersebut dikarenakan ia seorang perempuan serta waktu dan wilayah yang juga menentukan.

Beliau tidak dapat memimpin jamaah yasin tersebut dikarenakan ada pihak laki-laki (ustadz) yang memimpinnya, padahal semua anggota jamaah tersebut adalah perempuan dan ibu Salamah adalah seorang perempuan lulusan pondok pesantren yang sering digadang-gadang sebagai ustadzah. Kemudian beliau membentuk sebuah jamaah khataman al-Qur'an di dalam maupun di luar wilayah desa Sananwetan pada Jum'at siang sebagai bentuk emansipasi ataupun protes akan kebungkaman tersebut, selain itu terdapat pula kegiatan arisan qurban dan gerakan peduli kasih. Penelitian ini juga dipengaruhi oleh pihak-pihak lain yang terkait dengan penelitian.

\section{Sumber Data dan Lokasi Penelitian}

Sumber Data Primer : Jenis data yang dikumpulkan untuk kepentingan penelitian ini adalah data deskriptif yaitu wawancara dengan ibu Salamah sebagai salah satu nara sumber tentang fenomena pembungkaman peran pendakwah perempuan serta upaya peningkatan kegiatan dakwah tersebut sebagai sebuah bentuk emansipasi perempuan di desa Sananwetan kota Blitar,

\footnotetext{
${ }^{11}$ Lexy J. Moleong, Metodologi Penelitian Kualitatif , (Bandung; Remaja Rosdakarya, 1996), 26

${ }^{12}$ Sugiyono, Memahami Penelitian Kualitatif, (Bandung: CV. Alfabeta, 2007), 1-3

${ }^{13}$ Asep Saeful Muhtadi, Agus Ahmad Safei, Metode Penelitian dakwah, (Bandung: Pustaka Setia, 2003), 108

${ }^{14}$ Stephen W. Littlejohn, Karen A. Foss, Theoris of Human Communication, $9^{\text {th }}$ ed, (Teori Komunikasi Edisi 9), Penerjemah Muhammad

Yusuf Hamdan, (Jakarta: Salemba Humanika, 2009), 57
} 
Bpak Kyai Abdul Aziz dan Bapak Kyai Moch. Supartono sebagai pembanding, Bapak Samiran selaku ketua RT serta beberapa data yang berasal dari sumber lain berdasarkan observasi pada kegiatan-kegiatan dakwah yang ada

Sumber Data Sekunder : Merupakan data tambahan atau data pelengkap yang sifatnya untuk melengkapi data yang sudah ada, seperti buku-buku refensi tentang peran perempuan dan dakwah, majalah dan buletin yang menunjang serta situs-situs lain yang berkaitan dengan upaya peningkatan dakwah bagi kaum perempuan, teori-teori kelompok bungkam dan feminisme, dan lain sebagainya.

Lokasi penelitian ini adalah pada jamaah perempuan yasin dan khataman al-Qur'an di desa Sananwetan kecamatan Sananwetan kota Blitar.

\section{Tahap-Tahap Penelitian}

Identifikasi dan Penelitian Permasalahan di awali dengan mengungkap lebih dahulu latar belakang pentingnya permasalahan tersebut. Kemudian dilakukan perumusan masalah penelitian, tujuan penelitian dan perumusan hal-hal mendasar lainnya. Hasil langkah kedua ini berbentuk pengajuan judul penelitian ke akademik dan penyusunan proposal penelitian. Setelah itu, Menyusun kerangka pemikiran dilakukan pada saat Setelah judul dan proposal penelitian selesai disusun, disetujui dan lulus uji, maka disusun kerangka pemikiran terkait dengan konsep-konsep utama yang terdapat dalam penelitian ini. Kerangka pemikiran diperlukan untuk panduan dalam kegiatan koleksi data sehingga data yang akan dikumpulkan benar-benar terfokus sesuai dengan permasalahan penelitian. Berikutnya adalah menyusun perangkat metodologi, dan dilanjutkan dengan pengumpulan data, yaitu berupa pengumpulkan data deskripsi penelitian yang berupa fenomena pembungkapan secara psikologis terhadap peran pendakwah perempuan di desa Sananwetan kecamatan Sananwetan kota Blitar beserta upayanya dalam peningkatan peran tersebut.

\section{E. Teknik Pengumpulan Data}

\section{1) Wawancara}

Dalam penelitian ini, peneliti memilih menggunakan metode wawancara informal, yaitu sebuah wawancara yang menunjuk pada kecenderungan sifat terbuka dan tidak terstruktur sehingga seperti percakapan. Pertanyaan-pertanyaan mengalir secara spontan seiring dengan berkembangnya konteks dan situasi wawancara dan segala sesuatunya terasa sangat luwes (flexible).

Pertanyaan yang dikemukakan oleh peneliti dapat berbeda-beda antara subjek satu dan subjek yang lain, subjek yang sama kadangkala harus didatangi kembali oleh peneliti untuk pertanyaan yang berbeda atau mungkin mirip sehingga jawaban terdahulu mungkin dapat ditambahkan atau direvisi oleh subjek. Karena sifatnya yang longgar dan spontan, maka data yang terkumpul kerapkali sangat kompleks dan membutuhkan waktu lebih lama untuk mensistematisasi atau mengorganisasikannya.

\section{2) Observasi}

Sesuai petunjuk dari Lindlof, maka peneliti melakukan sebuah observasi sebagaimana berikut : ${ }^{15}$ (1) Engages the phenomenon for prolonged period of time (sustained), Peneliti telah mengikuti kegiatan tersebut serta berbaur dengan para ibu-ibu jamaah-jamaah dalam kurun waktu 2 bulan (2) Makes self-conscious and full, clearly expressed notations of how the observing is done (explicit), Rekaman wawancara yang merupakan data otentik dari peneliti mengenai pandangan, penilaian, keinginan dan perasaan-perasaan dari pendakwah perempuan di desa Sananwetan (3) Goes about the observing activity in an alert manner that allows for tactical improvisation (methodological), Peneliti terus menerus melakukan pengamatan

\footnotetext{
${ }^{15}$ Thomas Lindlof, Qualitative Communication Research Methods, (Thousand Oaks, London: Sage Publication, 1995), 134
} 
secara seksama sambil berimprovisasi, mengatasi persoalan yang ditemui, namun tetap berpegang pada strategi-strategi yang telah ditetapkan untuk mencapai tujuan penelitian (4) Impact attention to object in wats that are in some sense standardized, yet individually trainer (observing) Peneliti senantiasa menyadari posisinya sebagai peneliti, hal ini dilakukan agar dapat bekerja secara objektif, tidak menaruh kepentingan apapun dan dapat meneliti sesuai standard, tetapi tetap berimprovisasi bahkan berapresiasi tertentu (5) Textually construct and edits the observing (paraphrasing)(6) Embeds the observing in the interdependencies of place, actors and activities (sosial situations) (7) Differentiates the background elements of social situations that inform the object on which observing is focused (in relation to their occurring contexts).

3) Dokumentasi

Hasil penelitian dari observasi atau wawancara ini, untuk kredibelitas didukung dengan dokumentasi, autobiografi, sejarah pribadi serta fotografi sumber data primer ataupun sekunder.

\section{4) Teknik Analisis Data}

Setelah semua data terkumpul maka langkah seterusnya adalah mengolah dan menganalisa data dengan cara menyusun data ke dalam kategori, melakukan sintesa, menyusun ke dalam pola lalu membuat kesimpulan sehingga mudah difahami.

\section{5) Jadwal Penelitian}

Penelitian ini dilakukan secara berkala dalam kurun waktu sesuai kebutuhan peneliti, wawancara dan observasi pertama dilakukan pada hari Senin, 12 November 2011 pada jamaah yasin Senin malam di lingkungan desa Sananwetan Kecamatan Sananwetan Kota Blitar.

Peneliti melakukan pendekatan dengan subyek penelitian dengan cara mengikuti kegiatan yasinan dan khataman al-Qur'an tersebut setiap minggunya, sehingga dapat diperoleh data dengan mewawancarai nara sumber pada saat bertemu pada kegiatan tersebut setiap minggu selama kurang lebih 2 (dua) bulan hingga dirasa data telah cukup dan selesainya pembuatan penelitian ini.

\section{Penyajian dan Analisis Data}

\section{A. Deskripsi Objek Penelitian}

Karakteristik masyarakat Desa Sananwetan memiliki sistem nilai budaya (aturan moral) yang mengikat dan dipedomani warganya dalam melakukan interaksi sosial. Aturan itu umumnya tidak tertulis, seperti aturan tentang perempuan itu harus tunduk, patuh tergantung pada suaminya dan berada di sektor domestik saja (rumah tangga). Desa yang dihuni kurang lebih 5.250 (lima ribu dua ratus lima puluh) penduduk ini, memiliki agama yang mayoritas adalah Islam. Berjarak sekitar 2 (dua) km dari makam sang Plokamator dan Presiden pertama Indonesia Bung Karno ini menjadikan penduduk desa Sananwetan mempunyai jiwa nasionalis yang tinggi. ${ }^{16}$ Sehingga tidak heran, jika semangat nasionalismenya lebih tinggi dibandingkan semangat dakwah Islamnya. Desa yang memiliki kira-kira 5 (lima) kyai, 10 (sepuluh) ustadz, dan 2 (dua) ustadzah ini menjadikan dakwah Islam di desa Sananwetan di rasa cukup.

Para kyai yang biasanya berdakwah secara umum di masyarakat desa, baik jamaah laki-laki ataupun perempuan, juga sering diundang dalam berbagai undangan pengajian-pengajian, mantenan, khitanan, syukuran, slametan dan lain-lain. Para ustad yang membina pengajian iqra'

\footnotetext{
${ }^{16}$ Samiran, Wawancara, Blitar, 13 Januari 2012
} 
dan al-Qur'an bagi anak-anak, remaja ataupun dewasa yang tersebar di berbagai masjid ataupun mushola di desa.

Serta ustadzah, yang perannya sedikit terbungkam, dikarenakan budaya masyarakat desa yang kurang "membutuhkan" peran mereka ataupun karena kesibukan mereka dalam rumah tangga, yang mengharuskan mereka fokus menggurusi anak dan suaminya. Yasinan dan tahlilan merupakan kegiatan rutin di masing-masing RT di desa Sananwetan. Salah satunya adalah yasinan dan tahlil di RT.1 Rw. 03 desa Sananwetan. Adapun jadwal kegiatannya adalah pada malam Senin untuk jamaah perempuan dan malam Selasa untuk jamaah laki-laki, adapun pemimpin jamaahnya adalah bapak Kyai Moch. Supartono. Jikalau bapak Moch. Supartono berhalangan hadir, maka jamaah yasin tahlil perempuan akan diserahkan kepada Ibu Salamah. Namun hanya memimpin yasin tahlil saja, tidak ada ceramah agama seperti biasanya. ${ }^{17}$

Selain itu terdapat kegiatan diba' dan banjari, namun kegiatan ini hanya dilaksanakan oleh kaum laki-laki saja. Pihak perempuan dianggap tabu oleh masyarakat untuk menyuarakan suaranya dalam bentuk shalawatan dan biasanya menggunakan speaker sehingga dapat didengar oleh warga. Kegiatan para perempuan dalam dakwah Islam yang hanya berkutat dalam wilayah yasin dan tahlil saja, ternyata menjadikan mereka merasa kurang bebas bergerak. Apalagi peran ibu Salamah sebagai pendakwah perempuan hanya menjadi wakil pimpinan yasin dan tahlil. Ibu Salamah yang notabene adalah lulusan pondok pesantren di daerah Jombang ini merasa kurang leluasa mengembankan ilmunya kepada masyarakat. ${ }^{18}$

Sehingga beliau-pun berusaha menyuarakan kebungkamannya dalam berbagai bentuk aktivitas dakwah yang lain, yang mana dianggap aman dan sesuai syari'at. Karena tidak mengganggu aktivitas para mad'u pada keluarganya serta kegiatannya pun tidak menjadikan fitnah bagi mereka.

Adapun kegiatan-kegiatan yang telah dibentuk oleh pendakwah perempuan (Ibu Salamah) yang ada di desa Sananwetan sebagai upaya peningkatan perannya adalah :

1. Khataman al-Qur'an

2. Arisan Qurban

3. Peduli Kasih

\section{B. Penyajian Data}

\section{1) Aktivitas Dakwah Pendakwah Perempuan}

Dewasa ini, berbagai persoalan terjadi pada masyarakat Islam terutama di desa Sananwetan yang menuntut kaum perempuan berperanan aktif dalam bidang dakwah terutama kepada para kaum perempuan sendiri. Pendakwah perempuan akan lebih memahami tabiat, kedudukan dan permasalahan yang dihadapi oleh golongan perempuan sendiri. Mereka justru lebih bisa menarik hati para mad'u (sasaran dakwah) melalui pendekatan yang bersesuaian dengan fitrah kaum perempuan.

Pendakwah perempuan bukan saja menjadi role model $^{19}$, malah sumbangan mereka dalam menjaga kemajuan umat dapat membantu meningkatkan pembangunan masyarakat Islam. Pengaruh dan peranan pendakwah perempuan sejak dahulu, tidak lagi dinafikan, dan telah mempengaruhi perjalanan sejarah derajat kaum perempuan. Melalui dakwah, kaum perempuan menjalankan aktivitasnya dalam kehidupan masyarakat Islam serta bertindak sebagai satu komponen penting dalam sistem dan berpengaruh besar bagi pembangunan masyarakat Islam.

\footnotetext{
${ }^{17}$ Salamah dan Moch. Supartono, Wawancara, Blitar, 12 Januari 2012

${ }^{18}$ Salamah, Wawancara, Blitar, 12 Januari 2012

19 Juhari Hasan, "Dakwah Tektual dan Kontekstual", dalam Dakwah Tekstual \& Kontekstual, Peran dan Fungsinya dalam Pemberdayaan Ekonomi Umat, ed M. Jakfar Puteh, Saifullah, (Yogyakarta: AK Group, 2006), 180
} 
Pekerjaan para perempuan muslim di bidang dakwah di desa Sananwetan pada dasarnya memperkuat kerja dakwah para pendakwah laki-laki yang ada. Sangat menyedihkan bahwa peran ini begitu terlalu diabaikan dan diremehkan. Dengan sifatnya sebagai selimut spiritual dan psikologis manusia, sebenarnya pendakwah perempuan di desa Sananwetan dapat memainkan peran penting dalam dakwah di masyarakat.

Fakta bahwa penekanan akan pentingnya peran perempuan di desa Sananwetan dalam dakwah Islam tidak menjauhkan kita dari fitrah penciptaan perempuan terhadap dakwah. Biasanya, peran utama perempuan adalah pekerjaan dalam rumah tangganya. Aktivitas yang dilakukan oleh para perempuan di desa Sananwetan tidak hanya pergi keluar untuk salat di masjid, namun para pendakwah perempuan bisa mendirikan beberapa aktivitas lain yang dilakukan sebagai bentuk partisipasi dalam kegiatan dakwah Islam. Tentu saja, tidak satupun dari kegiatan-kegiatan tersebut bertentangan dengan kewajiban penting di rumah sebagai istri dan ibu. Dalam banyak kasus, inilah keseimbangan antara tugas-tugas penting perempuan itu dan persyaratan kerja dakwah, yang kadang kala telah menyebabkan masalah dan kesalahpahaman dalam keluarga dan masyarakat.

Ada banyak hal yang harus diperhatikan terkait kegiatan dakwah perempuan di desa Sananwetan. Tidak adanya pencampuran laki-laki dan perempuan yang harus diperhatikan dalam setiap kegiatan dakwah dan dalam keadaan apapun, misalnya cara berpakaian para pendakwah yang harus sesuai syar'i. ${ }^{20}$

Selain itu, pendakwah perempuan di desa Sananwetan juga memberikan persiapan psikologis, dengan memastikan bahwa para mad'u memiliki iman dalam ketulusan Allah, harapan, cakupan dalam kebenaran, kebanggaan dalam Islam, kesabaran, dan pengetahuan tentang kondisi dan lingkungan dari masing-masing individu tersebut. Ini adalah aspek yang sangat penting dari kesiap-siagaan, karena pendakwah terikat kepada orang-orang, yang memiliki karakter dan kecenderungan yang berbeda.

Pendakwah perempuan yang mempimpin jamaah di desa sananwetan, memberikan seminar, sharing, dan pengajian, khataman al-Qur'an dan lain-lain harus mampu membujuk para mad'u dengan mengatasi pikiran mereka melalui cara yang persuasif. Mereka juga harus mampu membangkitkan nafsu mereka, emosi, dan perasaan. Mereka harus berlatih menyampaikan materi dakwah untuk perempuan di masjid-masjid desa, sekolah-sekolah terdekat, atau tempat lain di mana para perempuan saling berkumpul. Mereka juga harus mengawasi dan membimbing peserta perempuan, dan dengan lembut memperbaiki kesalahan mereka. ${ }^{21}$

\section{Analisis Data dan Pembahasan}

\section{1) Nilai Pendakwah Perempuan di Desa Sananwetan dalam Kajian Teori Kelompok Bungkam}

Nilai seorang pendakwah perempuan di desa Sananwetan dianggap kurang berperan di masyarakat. Ide-ide yang mereka keluarkan, pada akhirnya selalu diatas namakan sebagai ide kaum laki-laki, yang dianggap lebih mumpuni dalam mengeluarkan ide-ide tersebut. Beberapa anggapan masyarakat yang menjadi pemicu pembungkaman para pendakwah perempuan di desa Sananwetan yaitu: ${ }^{22}$ (a) Anggapan mengenai kurangnya kemampuan dakwah oleh perempuan. (b) Anggapan mengenai terbatasnya sumber daya serta kurangnya inisiatif pribadi pada pihak perempuan. (c) Anggapan mengenai pengabaian atau kelalaian terhadap isu-isu perempuan dalam perencanaan dakwah Islam. (d) Anggapan mengenai tidak adanya tarbiyah yang kuat dan kurangnya pengetahuan Islam di bidang dakwah. (e) Anggapan mengenai kebanyakan perempuan tidak memiliki pemahaman yang tepat terkait peran dakwah, karena itu, mereka tidak dapat memahami pentingnya waktu yang diberikan

\footnotetext{
${ }^{20}$ Abdul Aziz, Wawancara, Blitar, 12 Januari 2012

${ }^{21}$ Salamah, Wawancara, Blitar, 12 Januari 2012

${ }^{22}$ Moch Supartono, Wawancara, 12 Januari 2012
} 
untuk proyek-proyek dakwah di luar rumah, sehingga seringkali menimbulkan permasalahan dalam rumah tangga. (f) Anggapan mengenai program dakwah oleh lembaga terhadap perempuan belum terorganisasi dengan baik.

\section{2) Upaya Perempuan untuk Peningkatan peran dalam Dakwah dalam Kajian Feminisme}

Di desa Sananwetan, upaya yang dilakukan untuk peningkatan peran pendakwah perempuan tersebut adalah dengan mendirikan majelis ta'lim, sebagai salah satu lembaga dakwah yang memiliki peran strategis dalam memperkuat wacana dan pengamalan ajaran Islam yang perlu menyesuaikan dan mengikuti perubahan yang terjadi pada masyarakat dengan melakukan proses pemberdayaan personal, kelembagaan dan pranata sosialnya.

Berkenaan dengan hal tersebut, pada penelitian ini akan dijelaskan tentang pemberdayaan majelis ta'lim perempuan oleh para pendakwah perempuan dengan alasan: ${ }^{23}$ Pertama, majelis ta' lim perempuan lebih eksis dibandingkan dengan majelis ta'lim laki-laki atau gabungan antara laki-laki dengan perempuan. Kedua, majelis ta'lim perempuan masih memiliki potensi luar biasa kurang mendapatkan sentuhan dari sisi manajemen dakwah yang modern sehingga aktivitasnya terkesan begitu monoton dan menjenuhkan. Ketiga, sumbangsih kaum perempuan dalam peran sosial politik di masyarakat kurang terorganisir dengan baik sehingga masalah-masalah sosial yang menimpa perempuan kerapkali terjadi di masyarakat, seperti kekerasan di rumah tangga, pelecehan seksual, penyiksaan tenaga kerja perempuan, dan sebagainya.

Dalam kajian teori feminis pada penelitian ini, dimunculkan secara khusus untuk menyoroti kedudukan peran pendakwah perempuan. Teori-teori ini berupaya untuk menggugat kemapanan patriarkhi dan berbagai bentuk stereotip gender lainnya yang berkembang luas di dalam masyarakat. ${ }^{24}$

Namun setelah sekitar 25 (dua puluh lima) tahun terbungkam, mereka berani berteriak lantang dengan melakukan perubahan sebagai upaya peningkatan peran mereka dalam dakwah, yaitu dengan dibentuknya sebuah aktivitas jamaah khataman al-Qur'an pada siang hari yang diikuti oleh Ibu-Ibu jamaah yang dipimpin oleh seorang ustadzah, arisan Qur'an yang dipegang oleh perempuan serta peduli kasih yang merupakan bentuk penyuaraan mereka akan kepedulian di masyarakat juga ruang lingkupnya yang menyebar baik di dalam maupun di luar desa Sananwetan.

Gerakan-gerakan ini adalah itikad baik dari para pendakwah perempuan di desa Sananwetan, dan semestinya mendapat dukungan bukan saja dari kaum perempuan tetapi juga seharusnya dari kaum laki-laki, tetapi mengapa kemudian banyak kritik diajukan kepada mereka? Memang memperjuangkan kesamaan hak dalam memperoleh pekerjaan, gaji yang layak, bersosialisasi di masyarakat dan dakwah, perumahan maupun pendidikan harus diperjuangkan, dan bahkan pemberian hak-suara kepada kaum perempuan harus diperjuangkan, namun tetap saja kaum perempuan juga harus sadar bahwa secara kodrati mereka lebih unggul dalam kehidupan sebagai pemelihara keluarga, itulah sebabnya adalah salah kaprah kalau kemudian hanya karena kaum perempuan mau bekerja lalu kaum laki-laki harus tinggal di rumah memelihara anak-anak dan memasak. ${ }^{25}$

\section{Kesimpulan}

Dari pembahasan-pembahasan di atas, dapat peneliti simpulkan bahwa perjuangan pendakwah perempuan untuk mendapatkan haknya dalam dakwah agar seimbang dengan para pendakwah

\footnotetext{
${ }^{23}$ Salamah, Wawancara, Blitar, 12 Januari 2012

${ }^{24}$ BP4 (Badan Penasehat Perkawinan, Perselisihan dan Perceraian). Membina Keluarga Bahagian Sejahtera. (Yogyakarta: BP4, 1991), 13

${ }^{25}$ Mufidah Ch, Psikologi Keluarga, (Malang: UIN Malang Press, 2008), 39
} 
laki-laki di masyarakat desa Sananwetan, tampaknya pada awalnya kurang dapat diterima oleh masyarakat desa Sananwetan itu sendiri. Emansipasi pendakwah perempuan yang dikembangkan oleh Ibu Salamah dalam kegiatan khataman al-Qur'an dan peduli kasihnya serta Ibu Utami dalam kegiatan arisan qurbannya, menempatkan pendakwah perempuan dan para perempuan lainnya menjadi selaras di masyarakat dan menjadikan mereka sebagai pendamping ataupun mitra bagi pendakwah laki-laki dan kaum laki-laki lainnya. Sehingga, dalam kehidupan bermasyarakat berikutnya, di desa Sananwetan telah terdapat pembagian kerja dan juga wilayah dakwah yang jelas diantara pendakwah laki-laki dan perempuan. Hal ini merupakan langkah awal bagi terciptanya suasana yang harmonis dalam rumah tangga dan juga di masyarakat.

Dalam kehidupan di rumah tangga dan bermasyarakat, terdapat kegiatan-kegiatan tertentu yang menjadi tanggung jawab seorang lelaki, ataupun menjadi beban seorang perempuan dan juga kegiatan yang dilakukan bersama-sama. Aktivitas dakwah merupakan salah satu tugas yang harus dilakukan secara bersamaan, artinya baik perempuan ataupun laki-laki memiliki tanggung jawab untuk melaksanakan dakwah. Meskipun dalam stratafikasi tanggung jawab itu berbeda, yaitu para pendakwah laki-laki memang memiliki beban yang lebih berat daripada pendakwah perempuan, namun peran pendakwah perempuan ikut menentukan keberhasilan misi dakwah. Peran pendakwah perempuan sebagai istri adalah membimbing rumah tangganya serta memberikan motivasi kepada para suaminya untuk ikut berjuang dalam menegakkan dakwah Islam. Selain itu perannya sebagai Ibu, yang tak dapat tergantikan adalah menanamkan nilai-nilai aqiqah dan ibadah kepada anak-anaknya. Hal ini merupakan wujud nyata keterlibatan mereka dalam proses dakwah.

Dalam rangka pelaksanaan kegiatan dakwah di desa Sananwetan, pendakwah perempuan telah berpartisipasi aktif dan mendapat sambutan hangat dari masyarakat dari berbagai aktivitas yang telah dilaksanakan. Seperti kegiatan khataman al-Qur'an bagi jamaah perempuan, arisan qurban bagi seluruh masyarakat serta peduli kasih yang dilaksanakan oleh ibu-ibu jamaah yasin tahlil bagi pemberdayaan masyarakat desa. Sejauh ini, aktivitas-aktivitas yang telah terlaksana tersebut tidak mengganggu peran mereka sebagai istri dan ibu. Suami mereka pun telah memberikan izin, dan bahkan mereka memberikan dukungan penuh dengan ikut berpatisipasi aktif dalam kegiatankegiatan yang telah dilakukan.

Dalam melaksanakan tugasnya sebagai seorang pendakwah, peran utamanya sebagai seorang ibu sebaiknya menjadi hal yang utama untuk dilaksanakan. Meskipun secara tidak sadar telah terjadi suatu pergeseran nilai dalam diri perempuan tersebut yaitu peran ganda seorang perempuan. Sehingga untuk menghadapi itu semua, sebaiknya seorang perempuan memiliki sikap moral dan religious yang kuat. Sebab dengan kedua sikap tersebut, akan mampu dipergunakan untuk mempertebal kepribadian, dan juga seorang perempuan bisa menempatkan dirinya sebagai seorang pendakwah dan sebagai seorang ibu rumah tangga yang ideal. Selain itu upaya-upaya peningkatan peran pendakwah perempuan menuju nilai-nilai positif itu haruslah di mulai dari diri sendiri dengan menampilkan sikap agung yang penuh dengan nilai-nilai tertinggi sebagaimana yang di ajarkan oleh Islam, seperti menutup aurat, bersikap lemah lembut, lapang dada, sopan santun, tanggung jawab, dan lain sebagainya.

Peneliti melihat bahwa kalaupun ada kecenderungan memposisikan pendakwah perempuan sebagai kaum kelas dua dalam masyarakat Islam, sebagaimana terjadi di desa Sananwetan kota Blitar, bukan disebabkan oleh faktor agama, budaya ataupun kurangnya dukungan dari sang suami tapi lebih karena faktor keragu-raguan, kurang kepercayaan diri dan kurangnya kesempatan yang diberikan kepada pendakwah perempuan untuk berkarya dalam dakwah

\section{DAFTAR PUSTAKA}

Anoraga, Pandji. 1992. Psikologi Kerja, Jakarta: PT Rineka Cipta

Banna (al), Hasan. 1987. Konsep Pembaharuan Masyarakat Islam, Terjm. Su'adi Sa'ad et.al, Jakarta: Media Dakwah. 
Bogdan, Robert dan Steven J. Tailor, 1975. Introduction to Qualitative Research Methods: A Phenomenological Approach to The Sosial Sciens, New York, John Wiley \& Sons.

BP4 (Badan Penasehat Perkawinan, Perselisihan dan Perceraian). 1991. Membina Keluarga Bahagian Sejahtera. Yogyakarta: BP4

Griffin, EM, 2003. A First Look At Communication Theory. Fifth Edition. New York, McGraw-Hill Companies, Inc. America.

Hasan, Juhari. "Dakwah Tektual dan Kontekstual”, 2006 dalam Dakwah Tekstual \& Kontekstual, Peran dan Fungsinya dalam Pemberdayaan Ekonomi Umat, ed M. Jakfar Puteh, Saifullah, Yogyakarta: AK Group.

Lindlof, Thomas. 1995. Qualitative Communication Research Methods, Thousand Oaks, London: Sage Publication.

Littlejohn, Stephen W. Karen A. Foss, 2009. Theoris of Human Communication, $9^{\text {th }}$ ed, (Teori Komunikasi Edisi 9), Penerjemah Muhammad Yusuf Hamdan, Jakarta: Salemba Humanika.

Megawangi, R, 1999. Membiarkan Berbeda? : Sudut Pandang Baru tentang Relasi Gender, Bandung, Mizan.

Moleong, Lexy J. 1996. Metodologi Penelitian Kualitatif, Bandung; Remaja Rosdakarya.

Mufidah Ch. 2008. Psikologi Keluarga, Malang: UIN Malang Press.

Muhtadi, 2003. Asep Saeful. Agus Ahmad Safei, Metode Penelitian dakwah, Bandung: Pustaka Setia.

Muis, Andi Abdul. 2001. Komunikasi Islam, Bandung: PT Remaja Rosdakarya.

Munir, Lily Zakiyah. (Ed), 1999. Memposisikan Kodrat, Bandung: Mizan.

Nazaruddin 1974. "Publistik dan Dakwah" Jakarta: Erlangga.

Patton, Michael Quinn. 2002. Qualitative Research \& Evaluation Methods $3^{\text {rd }}$ ed. Thousand Oaks: Sage Publication.

Pawito, 2007. Penelitian Komunikasi Kualitatif, Yogyakarta: Lkis Pelangi Aksara.

Punch, Keith. 1998. Introduction to Social Research: Quantitative \& Qualitative Approaches, London: Sage Publications.

Puteh, M. Jakfar. Saifullah, 2006. Dakwah Tekstual \& Kontekstual (Peran dan Fungsinya dalam Pemberdayaan Ekonomi Umat), Yogyakarta: AK Group.

Qahthani (al), Said Bin Ali. 1994. Dakwah Islam Da'wah Bijak; Jakarta: Gema Insani Press.

.Siahaan, M Hotman. 2006. "Metode Sosimetri”. Dalam. Metode Penelitian Sosial (Berbagai Alternatif Pendekatan, (ed), Bagong Suyanto dan Sutinah, Jakarta: Kencana.

Subandi, Ahmad. Syukriadi Sambas, 1999. Dasar-Dasar Bimbingan (Irsyad) dalam Dakwah Islam, Bandung: KP Hadid.

Sugiyono, 2007. Memahami Penelitian Kualitatif, Bandung: CV. Alfabeta.

Tim Penulis, 2005. Kamus Besar Bahasa Indonesia, Cet. Ke-3, Jakarta: Balai Pustaka

Umar, N, 1999. Argumen Kesetaraan Jender: Perspektif Al Qur'an, Jakarta: Paramadina.

West, Richard dan Lynn.H. Turner, 2008. Introducing Communication Theory: Analysis and Aplication, (Pengantar Teori Komunikasi Analisis dan Aplikasi), edisi 3, Penerjemah Maria Natalia Damayanti Maer, Jakarta: Salemba Humanika.

Zaini, M. Amin. 2006 "Dakwah dan Perubahan Sosial", dalam Dakwah Tekstual \& Kontekstual, Peran dan Fungsinya dalam Pemberdayaan Ekonomi Umat, ed M. Jakfar Puteh, Saifullah, Yogyakarta: AK Group 